Article

\title{
Sustainable Development According to the Opinions of Polish Experts
}

\author{
Mariusz Dacko ${ }^{1}$, Aleksandra Płonka ${ }^{1}$, Łukasz Satoła ${ }^{2, *}$ and Aneta Dacko ${ }^{3}$ \\ 1 Department of Economics and Food Economy, University of Agriculture in Krakow, al. Mickiewicza 21, \\ 31-120 Kraków, Poland; mariusz.dacko@urk.edu.pl (M.D.); a.plonka@ur.krakow.pl (A.P.) \\ 2 Department of Management and Economics of Enterprises, University of Agriculture in Krakow, \\ al. Mickiewicza 21, 31-120 Kraków, Poland \\ 3 Department of Agricultural Land Surveying, Cadastre and Photogrammetry, \\ University of Agriculture in Krakow, ul. Balicka 253a, 30-198 Kraków, Poland; aneta.dacko@urk.edu.pl \\ * Correspondence: lukasz.satola@urk.edu.pl
}

Citation: Dacko, M.; Płonka, A.; Satoła, Ł.; Dacko, A. Sustainable Development According to the Opinions of Polish Experts. Energies 2021, 14, 5325. https://doi.org/ $10.3390 /$ en14175325

Academic Editor: Alexey Mikhaylov

Received: 20 July 2021

Accepted: 25 August 2021

Published: 27 August 2021

Publisher's Note: MDPI stays neutral with regard to jurisdictional claims in published maps and institutional affiliations.

Copyright: (c) 2021 by the authors. Licensee MDPI, Basel, Switzerland. This article is an open access article distributed under the terms and conditions of the Creative Commons Attribution (CC BY) license (https:// creativecommons.org/licenses/by/ $4.0 /)$.

\begin{abstract}
The idea of sustainability has been exerting an impact on public awareness for nearly five decades. However, representatives of various sciences interpret it in many different ways, and there were several hundred definitions of it already at the end of the 20th century. There is no doubt that a proper understanding of the essence and meaning of sustainable development by opinion leaders representing various scientific disciplines determines transformations in particular sectors of the economy, especially in the energy sector. Economics, which considers the relationship between the economy and the environment, seems to have a special role with regard to this issue. Models and concepts of managing limited environmental resources are considered based on this science. Thus, economists have a kind of greater responsibility for the shape and direction of development, and especially for whether it will be durable and balanced. With these issues in mind, the aim of this paper is to review and systematize the opinions of Polish experts on the concept of sustainable development and to indicate the most important parameters that define it. The paper presents the results of an opinion survey of 105 experts affiliated with a wide variety of institutions. Respondents represented economic, technical, social, and natural sciences.
\end{abstract}

Keywords: natural resources; sustainable development—interpretations; sustainable developmentexperts' opinions

\section{Introduction}

Key issues related to human economic activity and its effect on the environment have been recognized and emphasized in the European Union for many years. As time passes, it is becoming clear that without decisive action to reduce the pressure of the economy on ecosystems, it will not be possible to sustain the current level of economic growth. This pressure is very high for a number of reasons. One is that the super-industrial era economy is still based on fossil fuels. Half of the total energy consumption of the last two thousand years has been consumed by humans during the last century of this period [1] Unfortunately, with the passing of decades, this disproportion has increased even more, and the need for constant energy consumption has grown to become the biggest addiction of modern civilization. According to the BP Statistical Review of World Energy [2] in 2019, the world will consume more than 14,000 Mtoe, and global consumption is growing at $178 \mathrm{Mtoe} /$ year. In just 50 years, energy consumption has increased more than four times worldwide [3]. The industry website "The World Counts" warns that modern civilization is utilizing so many resources that continuing these trends will soon require a second Earth [4]. Yet, the issue of the predicted consequences of continuing unlimited growth on a planet with limited resources had already been raised in the 1970s by Meadows [5] in a report prepared for the Club of Rome. 
If, entering the new millennium, Chinese residents wanted to drive cars and burn as much fuel as Americans, China alone would consume more than 80 million barrels of oil per day, more than the then global production estimated at 74 million barrels [6,7]. Although the world still has enough oil, the moment when its production will reach its maximum is not necessarily so distant [7]. The results of the models developed by Norouzi et al. [8] suggest that global energy demand and supply should be prepared for this phenomenon as early as the third decade of the 21st century.

According to the BP Statistical Review of World Energy [2], "the biggest addiction of modern civilization" is still satisfied at a global level of as much as $95 \%$ from non-renewable sources. The substitution of these energy sources with other sustainable energy sources, although accelerated (especially in the EU), has been too slow for many decades, and, in this context, the improvement and even the preservation of the current standard of living of future generations are in question.

Undoubtedly, the authorities of the European Union are aware of this. It translates into the educational and information campaigns undertaken, the legislative sphere and the instruments used to implement community policies. The energy and climate policy are of key importance in this area, becoming one of the most important and setting the benchmark for many other activities at the community level. These policies influence the formulation of national policies in member states.

Sustainable development (SD), particularly of the energy sector, is currently an overarching global goal. The 2030 Agenda for Sustainable Development, adopted in 2015 by all UN member states [9], identifies 17 Sustainable Development Goals (SDGs) that the world should achieve by 2030. These goals, according to Kamali-Chirani [10], are very diverse and broad: from the elimination of "poverty" and "hunger" to "quality education" and "developing life underwater". In addition to the key issues of rational resource management, promotion of stable and sustainable economic growth, and social welfare, the issue of stable, sustainable, and modern energy has been given key importance among them [11]. Indeed, there is a need to ensure universal access to affordable, reliable, and modern energy services [12,13], increase the share of renewable energy sources in the global energy mix, double the growth rate of global energy consumption efficiency, and increase international cooperation to facilitate access to clean energy research and technology in the areas of renewable energy, energy efficiency, and advanced and cleaner fossil fuel technologies [14], all by 2030 .

The quest for stable, sustainable, and modern energy has crossed impacted European Union policy; sustainable development is expected to lead to ensuring the economic growth of the community, the welfare of its citizens, and to increasing the quality of life of present and future generations. In turn, the achievement of the adopted goals will be possible through economic development, taking into account environmental protection and social justice $[15,16]$.

According to the accepted assumptions, the European Union is moving towards a low-carbon economy [17-19]. This is treated as a priority for systemic transformation to create competitive advantages in a globalized world [20]. Nevertheless, beyond economic objectives, addressing the challenges of climate change and environmental degradation are strongly emphasized [21,22].

The transformation of economic models towards the efficient use of resources and reduction of greenhouse gas emissions has become one of the fundamental challenges of civilization. Despite the uncertainty surrounding long-term forecasting, there is a growing consensus among the international community that, without a significant transformation of economic models in how natural resources are used, the global economy will be increasingly vulnerable to the consequences of climate change, irreversible loss of some resources, and rising energy commodity prices [23,24].

The discussion around climate change, its relationship to sustainable development, and the accompanying attempts to construct global, regional, and national climate policies, [25] revolves around the issue of energy sources and energy policies. This is because 
most emissions of the major greenhouse gas $\left(\mathrm{CO}_{2}\right)$ come from the use of fossil fuels as an energy source.

According to D.W. Pearce [26] and R.K. Turner [27], in relation to the management of energy resources, the idea of sustainable development is the search for the optimal use of energy resources to ensure socio-economic development that takes environmental requirements into account. The authors explain that sustainable development in the field of energy is an integrated effort on both the supply and demand side, using available, innovative technologies, placing the least possible burden on the environment, and improving the quality of life.

Presentation of the importance of sustainable development in the energy sector is, nowadays, becoming one of the main determinants of development and transformations occurring in this sector of the economy. The attempt to combine energy, economics, and protection of the natural environment in the context of sustainable development contributes, among other things, to the interdisciplinary approach of researchers in applied sciences, the introduction of smart technologies, the search for opportunities to improve energy efficiency in mature energy technologies, the diversification of sources for raw materials of strategic importance, the development of renewable energy, and greater care for the natural environment [28,29]. Political science, economics, and sociological sciences have also conceptualized the research topic of the impact of sustainability policies on economic and social change. This issue is also emphasized in studies related to the development of both urban and suburban, peripheral and rural areas [30-33]. Because of the critical importance of energy to most sectors of the modern economy, transformations in this sector will determine the success of the business models of many industries [34,35]. Having considered the foregoing, it is crucial to properly define the concept of sustainable development (SD) and to indicate the most important parameters defining it. It seems particularly important for opinion-forming circles representing various scientific disciplines, especially economists, to understand the concept of sustainable development. After all, it is economics that has considered the relationship between the economy and the environment since its inception, and it is on the basis of economics that models and concepts of managing limited resources are considered [36,37]. It is economists who have significant responsibility for the shape and direction of development, especially whether it will be durable and balanced.

\section{Literature Review}

\subsection{Sustainable Development-The Origins of the Idea and Its Development in the International Arena}

The first concrete demand for sustainability was formulated for forest resource management in Saxony. The principle of sustainability in forest management, developed by Hans Carl von Carlowitz [38], was to cut only as many trees as could grow in the expected period so that the forest would not be eliminated, allowing it the possibility to regenerate naturally instead. In forestry, the concept of sustainability was simple, measurable, precise, and feasible. It boiled down to respecting the natural restorative capacity of the forest and deriving lasting (rather than one-time) benefits. By the 19th century, Carlowitz's concept had been widely promoted by German forestry schools and was later adopted by scientists elsewhere in Europe. The term sustainable was adopted by the environmental movement in the second half of the twentieth century and was then increasingly emphasized in the international political debate. According to Normalisa Md Isa, Arunnaa Sivapathy, and Nur Nadia Adjrina Kamarruddin since the 1970s, sustainable development developed from science and the environmental crusade [39].

With the release of the World Conservation Strategy document in 1980 [40], the concept of sustainable development became firmly established in concepts of environmental and resource management. There were three dimensions pointed out in sustainable development: economic, social, and environmental. Not only the interaction between the goals was stressed but also the correlation and the necessity of collective action to reach the aims [41].

In 1987, its meaning was clarified under the auspices of the UN World Commission on Environment and Development. At the time, a report called the Brundtland Report, au- 
thored by Gro Harlem Brundtland, the chair of the Commission, was published, providing a definition of sustainable development. According to this report, sustainable development is development that ensures that the present needs of society are met without compromising the ability of future generations to meet their needs $[33,42]$. Such a definition dominated the understanding of sustainable development in the 1990s [43]. However, even then it was so vague that in 1996 (less than 9 years after the report was published), Dobson [44] identified over 300 definitions and interpretations of the concept of sustainability [45]. Renko also mentions its various definitions [46].

Literally, SD would simply mean "development that can continue indefinitely or for a finite period of time" [47-50]. Mensah [51] points out that in its structure, the phrase consists of two words: development and sustainable. Just as each of these words can be understood from different perspectives, the entire concept of SD can be viewed differently. This fact explains the multiplicity of definitions.

According to Harwood [52], sustainable development means unrestricted development focused on achieving greater benefits for humanity and more efficient use of resources with consideration of the environment that is essential for both humans and other biological species.

In the study Caring for the Earth, a Strategy for Sustainable Living published in partnership by the International Union for Conservation of Nature and Natural Resources, the United Nations Environmental Programme and the World Wildlife Fund, sustainable development means "improving the quality of human life while living within the carrying capacity of supporting ecosystems" [53].

Lele [49] views SD as a process of intentional change that can always be repeated. On the other hand, Starling [54] views it as reconciling the interests of the economy and the environment on a new growth path that will enable the long-term sustainability of humanity. According to other researchers [55], sustainability offers the possibility of indefinite interaction between society, ecosystems, and other living systems without depleting key resources. Back and Wilms [56], on the other hand, state that sustainability is a powerful global contradiction to contemporary Western culture and lifestyles. For others, environmental protection is key to sustainability. While this is a simplification, there is no denying that the state of the environment is a key determinant of sustainable development [57].

In Poland, SD also initially referred to the environment, and the concept of ecodevelopment dominated in Polish science. It has gradually been supplanted by the term sustained development. Numerous Polish interpretations of the sustainable development concept have been around since the 1980s. The literal translation of sustainable development in the Polish literature was identified with durable, continuous, lasting, and uninterrupted development. However, the accuracy of these translations has long been debated, and the concept of sustainable development has finally gained the upper hand [58].

Over the years, the initially simple concept of sustainability, which referred to the issue of the long-term management of forest resources, has evolved. It has been generalized to the entire sphere of socio-economic human activity with particular emphasis on the fuzzy and hard-to-measure context of intergenerational justice [59]. With a relatively small contribution from the natural sciences (which are generally in opposition to economic interference in the environment), the concept has been intensively developed in the social sciences, primarily economics, philosophy, and political science. Although a plethora of SD interpretations have been developed, they generally did not relate directly to the operation of the energy sector in the early days.

\subsection{Sustainable Development as a Paradigm}

Like any new idea that arises out of the crisis of the paradigm that preceded it, sustainable development has been forced to make a sufficiently strong appearance, becoming the subject of polemics in scientific circles and discussions in the pages of journals. It has had to break down outdated views and stereotypes in a revolutionary way. This was also the case 
with SD, which at an exponential pace has inspired more and more scientists, politicians, and journalists. The number of websites that mention the term "sustainable development" in various contexts has grown exponentially, and, as a result, the term sustainable development can be found in over 20 million different sources. It is not difficult to notice that the growing popularity of views advocating balanced development, its durability and interand intra-generational equity has become directly proportional to the piling up nuisances and problems that modern civilization faces. Energy production and consumption, and their multifaceted effects, have played a significant role among these problems.

In many works, sustainability has been elevated to the status of a new paradigm (e.g., [60-62]) replacing profit-maximization and material production thinking, a model of thinking that has reigned unchallenged in economics for nearly 250 years. At the same time, the idea has continued to generate a lot of controversy. Economists have varied in their assessments of the validity and anticipated consequences of pushing this normative demand. According to advocates of state interventionism who proclaim the frailty of the free market, these demands should be beneficial $[63,64]$. On the other hand, representatives of the liberal trend are against the idea of sustainable development, claiming that no top-down interference in the economy will bring better results than leaving it to its own devices [65]. There are even views presented that the economy, once it has emerged from its infancy, will naturally gain the appropriate maturity and develop a respect for the environment without unnecessary regulations. However, sustainable development is currently, at least at the level of the slogan, an almost inseparable element of policies, climate and energy strategies, and plans developed at international, national, regional, and local levels. This concept is addressed in constitutions and laws. In Poland, the legal definition of sustainable development is specified in the Environmental Protection Law [66]. This is a strongly theoretically developed definition, which is referenced in the constitution and many environmental management laws [67-70]. This definition says that sustainable development is social and economic development in which the process of integrating political, economic, and social activities takes place with maintenance of the natural balance and durability of basic natural processes, in order to guarantee the possibility of satisfying the basic needs of particular communities or citizens of both present and future generations. Sustainable development is prevalent in international agreements, treaties, and conventions that deal with the broadly defined natural environment and its protection through the optimal use of energy resources. Sustainable development is now one of the basic principles of international relations and belongs to the canon of EU policy. A paradox becomes apparent here: despite this, in social reality, evidence of the functioning of the idea of sustainable development remains barely visible (with few exceptions on a local scale).

Sustainable development relatively quickly became an interdisciplinary issue of broad interest to representatives of, among others, philosophy, economics, ecology, law, political science, and sociology. Scientists, however, have looked at sustainable development in an isolated way, appropriate to the specifics of the scientific discipline they represent, but at the same time usually abstracted from other disciplines. This has given rise to misunderstandings and controversies, some of which are cited below as exemplifying contemporary problems with the understanding and implementation of the idea in question.

Fundamental consideration of the concept of sustainable development has been undertaken in the social sciences, primarily in economics and philosophy. Valuable methodological inspiration was also drawn from the general systems theory postulated by Bertalanffy [71]. However, Zablocki [72] points out an interesting aspect. Natural sciences were much less important in shaping the idea of sustainable development, even though environmental change was the main concern of scientists. Most publications on how to respond to threats have been economic, philosophical, and political [73-75]. It seems that this may have been one of the underlying causes of today's controversies that have arisen on sustainability issues at the intersection of the social and natural sciences and, in particular, in the confrontation between economics and ecology. 
As it turns out, from an ecologist's perspective, the very postulates of striving for ecosystem balance are debatable. It is not good for the ecosystem when nothing changes in it: it is man who prefers that nothing changes there. This widespread myth about the need to maintain balance in ecosystems is the result of a longing for paradise lost. It is also not so obvious that balance in nature is beneficial to man. Long-lived ecosystems, such as those formed in Poland in the Białowieża National Park, are the closest to equilibrium, but, while there is a will to protect them, productive farmland is far more valuable to humans. Forests also have been, are, and will continue to be exploited by humans for profit before they reach the climax stage, as stated by Weiner [76].

Human activities are irreversibly remodeling ecosystems, and one must eventually come to terms with the fact that with today's level of industrialization, it is impossible not to interfere with ecosystems. Moreover, biocoenoses can develop in states far from equilibrium without much difficulty and these can be quite natural processes in the environment [77]. Development aimed at a dynamic equilibrium in nature is therefore, from an ecologist's point of view, an oversimplification because this equilibrium does not necessarily benefit the environment.

Throughout human history, the need to rationalize resource use has often emerged as a belated response to cumulative problems, to visions of intractable barriers to growth, and to signals of impending crisis. In such a situation, immediate actions taken to "fix the world" should be even more thoughtful and careful, contrary to appearances. As experience shows, delayed responses have the tendency to become disproportionate to the cause and subjective. They are often accompanied by emotions, which, according to Austrian economist Ludwig von Mises, distort the evaluation of inputs and outputs: to a person who is not guided by cool deliberation, the goals may seem more desirable and the associated inputs lower [78]. In the absence of prudence, there is even the possibility of a completely incorrect assessment of the situation. The demands of sustainability are certainly not ill-intentioned. Nevertheless, a distanced caution is inevitable given that the implementation of these demands implies the need for national and/or international regulations. In matters of legal interference in the economy (including energy), one should be careful and be able to distinguish between man-made situations that actually require radical change, and apparent, imaginary problems that are the result of hysteria.

The idea of sustainability places constraints on the economy by postulating actions that ensure inter- and intra-generational equity [79] in the management of limited environmental resources. Their implementation is expected to have beneficial effects on the environment and the society managing it. However, there is no denying that this is a controversial concept even from the perspective of just a single academic disciplineeconomics. Adam Smith has already questioned the wisdom of politicians not afraid to substitute market judgments with their own. Balancing development is not possible without interference in the market and in real social and economic processes, i.e., interference resulting from the conviction that they require correction because they are malfunctioning. Many of the hidden effects of this interference cannot be easily predicted. History has repeatedly shown that in a complex dynamic system such as the economy, these effects can even be completely unintentional and undesirable. Therefore, economists such as Adam Smith, John S. Mill, Frederic Bastiat, Ludwig von Mises, Henry Hazlitt, and Friedrich A. von Hayek have been opposed to state interference in economic processes. The father of classical economics, Adam Smith, argued that free markets usually produced better results in the economy than government intervention [80]. Ludwig von Mises believed that progress was made only by liberal policies [81] that applied the findings of economists in practice. According to Bastiat, the function of law should never be to regulate human consciences, ideas, will, opinions, works, talents, or pleasures [80]. He also stated that whenever there is a temptation to regulate the economy in any way, one should keep in mind not only what can be seen (the direct effect of the new legal norm) but also what cannot be seen (the many indirect effects). The immediate consequences of regulation (what you can see) are usually beneficial, the later consequences (what you cannot see) 
are often fatal. Sometimes the opposite happens, but there are many aspects of every adjustment, not just those that are immediate and intended. Therefore, a good economist, before postulating the implementation of sustainable development, should be able to see and predict all of these aspects.

It cannot be overlooked that the idea of sustainability comes into collision with the common-sense view of the classics, that economics should be positive rather than normative. Economists should answer the question "how is it?", not "how should it be?" Ludwig von Mises believed that economics does not mention goals and should never tell a person how to act. It should only indicate what can be done to achieve the goal [78]. William Nassau Sr. argued that, as a scientist, the economist can only point out the consequences of various economic actions or the possible means of achieving various goals. However, they should never leave the field of positive scientific analysis and make value judgments about desirable courses of action: they should deal with what is, not what should be [80]. Meanwhile, sustainability economics is a decidedly normative economics—valuing, postulating, and correcting.

Currently, there is no shortage of voices saying that the postulates of sustainable development are a pipe dream and will forever remain in the realm of wishful thinking, as they are impossible to achieve in practice. Is sustainable development really just the realm of dreams for eco-intellectuals? Markets will probably never be free of externalities, and neither will their imperfect subject, man, be free from the temptation of greed and dishonesty that accompanies the pursuit of goals at the lowest possible cost. This is also perfectly evident in the energy industry.

Against the backdrop of these numerous doubts, it is possible to express the view that the issues of sustainability - as paradigms-are and will be extremely difficult to reconcile from the point of view of different scientific disciplines (and each individual discipline as well). Neither economics, nor ecology, nor philosophy, nor any other science can independently define sustainable development and relate it to individual areas of the economy. Interdisciplinary knowledge and a holistic approach seem to be necessary; a holistic approach that departs from radicalism in the sense of categorical normative statements.

\subsection{Sustainable Development-Ambiguity of Definition and Its Addressees}

The concept of sustainable development according to Jeżowski [81] is not only a serious cognitive problem but also a practical one. It is understood in many ways, and the policies and strategies implemented in accordance with it can have markedly different content and scope. In addition, Korol [44] admits that among the many definitions of sustainable development presented to date, one can observe great differences in the understanding of its essence. According to Boltromiuk [82], the multiplicity of contemporary definitions and differences in exposing the principles on which the concept of sustainable development should be based, results from the fact that it does not only concern the ecological conditions of development but also includes an entire spectrum of other issues, such as demography, health care, education and culture, the problem of social inequality, and security. The views of researchers are diverse or even contradictory, ranging from the question of defining the axiological basis, through the objectives and principles, to the instruments and institutions for the implementation of sustainable development. Although the discussion on the essence of sustainable development has been going on for almost 30 years, Borys [83] rightly states that one can get the impression that it is still in its infancy. According to his views, the concept is still not well established in economic science, and this state of affairs is hardly surprising since the issue of SD, its understanding, desirability, and multiple consequences, are still fuzzy, unclear, and controversial issues from the point of view of both economists and ecologists. In fact, it is still not very clear how to implement sustainable development and evaluate the degree of its implementation.

Zylicz [84] noted that the declarative-normative nature of the durability postulates may arouse disappointment that people do not act as they should act in their own wellunderstood interests. The idea was criticized by Sztumski [85], who thought that due to 
the troubles with its realization, it plays the role of a myth that is fed to society today. This is because there is more wishful thinking than practical thinking at the core of sustainable development, and successive "Earth Summit" resolutions and ideas of sustainable development are characterized by poor feasibility. Perhaps they are the result of naive, albeit lofty optimism and wishful thinking on the part of good people. Nevertheless, they can also be an element of deliberate manipulation, a deliberate distraction of the public from reality by creating another illusion.

Despite this, however, it seems that the idea of SD will not become completely obsolete, although undoubtedly the biggest challenge to it will be trying to operationalize and implement it. The effects of these attempts (probably mediocre, as socio-economic systems are characterized by high inertia and limited susceptibility to control) will determine the further evolution of the idea of sustainable development. Perhaps it will move in the direction of its mitigation and liberalization in line with the environmental Kuznets curve, indicating that it is sufficient for a society to have an adequate level of welfare for environmental pressures to systematically decrease. Nevertheless, it is possible that the opposite will happen, and along with the cumulation of environmental and social problems the tendency to radicalize the concept of sustainable development will intensify, and thus also to increase the scale of interventionism, including in the energy sector.

Today, sustainability is increasingly considered in the context of durability. In the scientific community there is an ongoing debate on what this durability should be: weak, i.e., ignoring the changing structure of capital and allowing for the possibility of its substitution, or strong, i.e., postulating the necessity of preserving each resource separately and excluding the substitution of natural capital with anthropogenic capital. Extreme demands for strong durability would probably win the approval of environmentalists, but they seem completely unrealistic from an economist's point of view. Bajerowski said: “(...) ecological space is currently a concept opposite to the concept of economic space, with which it enters into a victim-predator type of relationship". This author believes that in all human endeavors of environmental interference, economic aspects should not be forgotten. This is because the measures taken to protect and shape the environment have varying degrees of effectiveness. These are usually enforced by law. Still, they can also be realized in an unforced and natural way when the set environmental goals are accompanied by measurable economic benefits [86].

Domański [87] believes that the pursuit of intergenerational equity should be a nonzero-sum game. In his view, the sum of resources extracted from the environment by the present generation need not equal the sum by which the resources of future generations will be depleted. The progress of science, invention, and innovation make it possible to specifically combine the resource limitation and assimilative capacity of the environment with human knowledge and capabilities. Thanks to progress, some limited natural resources may not only not be depleted but there could even be an increase. The share of material resources in the value of national income will decrease, while the share of information will increase (dematerialization of national income). However, can the substitution of natural capital with anthropogenic capital compensate future generations for a lack of access to some environmental resources that are still in relative abundance today? There is no shortage of far more radical voices on the issue of durability. The limited possibilities of the substitution of natural capital and the need to respect the postulates of stronger durability are emphasized by the precursors of ecological economics (e.g., [88,89]) and sustainable economics [90].

Durable system development is first and foremost a process. It is therefore inseparable from time. There is a growing group of researchers exposing the system-dynamic character of sustainable development (e.g., [86-89,91]). One of the earliest definitions that takes into account the systemic-dynamic nature of sustainable development states that sustainable development involves the simultaneous maximization of the goals of biological systems (e.g., maintaining their diversity, durability, and productivity), economic systems (e.g., meeting basic needs, increasing production, and consumption of goods and ser- 
vices), and social systems (e.g., maintaining cultural diversity, institutional durability, and social justice) [88]. According to Constanza [89], one can talk about sustainable development when the relationship between man-made dynamic economic systems and dynamic ecological systems provides stability and development of human life, opportunities for development and self-realization of individuals, and preservation and development of human culture.

From the perspective of systems theory and engineering, coherence manifested in the fact that changes in one element of the system have a significant effect on changes in other elements of the system is an important characteristic of systems. Thus, for socioeconomic systems to coexist permanently with ecological systems, they cannot exclude and destroy each other. According to Michnowski [91], man-made systems should consistently respect consequences. This happens when, in the overall balance of their functioning, there is an apparent predominance of externally constructive elements (which promote the development of other elements of the system) over externally destructive elements (which develop at the expense of other elements of the system).

Bajerowski [86] believes that sustainable development is a dynamic optimization process involving the search for a development path that ensures the minimization of environmental damage and maximization of environmental benefits. This author views sustainable development as the striving of a dynamic economy-environment system to a stable state. The theoretical image of sustainable development in Bajerowski's original understanding will thus be a particular trajectory (during the period of mutual adjustments of the system) or a point (when these adjustments cease) in the phase space of all possible states of the system. Adjustment changes in the economy and environment should stop when the system reaches a socially acceptable state. On the other hand, according to Sandner [77], ideas of sustainable development can only apply to a system at the ecosystem level. However, the sustainability of an ecosystem is only theoretically possible: the number of variables that make up its functioning is so great that there is not and never will be a way to study them all together.

Contemporary definitions of sustainable development continue to expose a variety of viewpoints. According to Korol [43], sustainable development means ensuring durable improvement in the quality of life of generations through the formation and realization of appropriate proportions between economic, human, and natural capital. This researcher adds that the effectiveness of the introduction of the sustainable development concept depends strictly on the development and implementation of diagnostic and prognostic indicators as tools for its measurement. There are two basic spaces of balancing development: intersystemic, focusing on the relations between the economy, society, and the environment, and intrasystemic, aimed at shaping individual orders, ecological, economic, and social. Jeżowski [81] stated that there is no particular focus on balancing in the literature (outside the Polish tradition) and we have an overuse of the word "sustainable" in its literal sense. According to this author, the essence of sustainable development does not lie at all in balancing the relationship between the different and hardly comparable components of the economy-society-environment system; the key issue is durability. Then again, Kiełczewski [92] noted that since the late 1980s, one can see a clear tendency to gradually expand the range of problems, the solution to which has become the ambition of sustainable development policy. This author describes the discussed concept based on the European Union Sustainable Development Strategy. This strategy says that sustainable development means socio-economic development balanced with the environment to meet societal expectations and aspirations in terms of prospects for satisfying needs and self-fulfillment. According to Runowski [58], given the current substantive capacity and message of the term, it seems most accurate to say that sustainable development is the pursuit of balance between the various objectives of socio-economic development, without which it is difficult to maintain the long-term durability of the system. At the same time, the concept of durable development sets, as it were, the main goal, which is to ensure the stability and continuity of the system. The term sustainable development, on the other 
hand, indicates the way to achieve the goal of durability. It is impossible not to agree with this author: unsustainable development cannot be durable. This seems to be one of the more balanced, concise, and reasonable definitions as of today.

\section{Materials and Methods}

The aim of the study was to find out the opinion of Polish experts on the idea of sustainable development and selected aspects of its effect on society. The main premise was that the concept of sustainable development was formed on theoretical grounds that are unclear to the average citizen. This can result in a misunderstanding of the definitions, basic assumptions, and addressees of sustainable development.

The data was obtained using a questionnaire containing 23 questions on sustainable development. They raised the following issues:

- interpretation of SD and evaluation of its legally binding definition in Poland;

- evaluation of a number of alternative definitions;

- impact of SD on society;

- the role of economics in promoting SD;

- the scope of necessary education for SD;

- entities responsible for the promotion and implementation of SD;

- opportunities to achieve SD at global, national, regional and local levels;

- major SD problems at the global, national, regional and local levels;

- the effectiveness of a number of proposed actions for the implementation of SD.

A survey questionnaire also contained 4 questions characterizing the respondent. The questions in the questionnaire were both open-ended and close-ended. In the open-ended questions, a written answer was asked in the form of a comment. The answers given by the respondents to the following questions included in the questionnaire were adopted for further analysis:

1. Do you share the view that sustainable development has become a paradigm (pattern, model of conduct, worldview) of modern civilization?

2. In your opinion, is the definition of sustainable development, which is legally binding in Poland, formulated in such a way that not only the authorities but all citizens should feel that it is addressed to them?

3. In your opinion, are the principles of sustainable development so well understood by society that it can be an informed and active implementer of them in everyday life?

4. With a view to explaining the essence of the idea of sustainable development to society in the best possible way (so that every citizen can implement it in everyday life), please evaluate the different interpretations suggested below (Table 2).

There were four possible options as a response to the closed-ended questions 1-3, (Figure 1): YES, RATHER YES, RATHER NOT, NOT and I HAVE NO OPINION. In the case of the question (command) number 4-in light of the literature search conductedrespondents were presented with ten different definitions of the SD concept and asked to rate each definition in the categories of convincing or not convincing (Table 2). Before starting the study, the survey was consulted among representatives of economic, natural, social, and technical sciences from several academic centers and research institutions in Poland. Pilot studies (preliminary tests) were also carried out to check the readability and validity of the questions in the questionnaire.

The study was initiated in early 2018. The survey questionnaire was distributed to a wide range of experts dealing with sustainable development in different professional fields in two versions, i.e., traditional (paper), through direct contact with the respondent, and electronic. The sample was collected using the method of competent judges. This method allows for the objectification of assessments of data collected in the course of qualitative research, thanks to a group of people-assumingly competent in a given field-assessing specific research aspects. Their ratings are then averaged and used in further statistical analyzes. According with methodological assumptions, the selection of the research sample 
was purposive. Competent judges, experts, were invited to take the survey: research and teaching staff of universities and employees of research units and institutes professionally involved in the issues of sustainable development (i.e., with scientific achievements in the field of SD, recognized in the national scientific community as specialists in the subject of $\mathrm{SD}$, with an academic degree/title). Moreover, this group also included employees of state and local administration units, members of foundations and associations related to the idea of sustainable development, and those experienced in the practice of SD. The profile of respondents is presented in Table 1.

Has SD become a paradigm (model of conduct, worldview) of contemporary civilization?

Is the law definition of SD formulated in such a way that not only the authorities, but all citizens should feel like its addressees?

- Are the principles of SD so well understood by society that in everyday life it can be their conscious and active implementer?

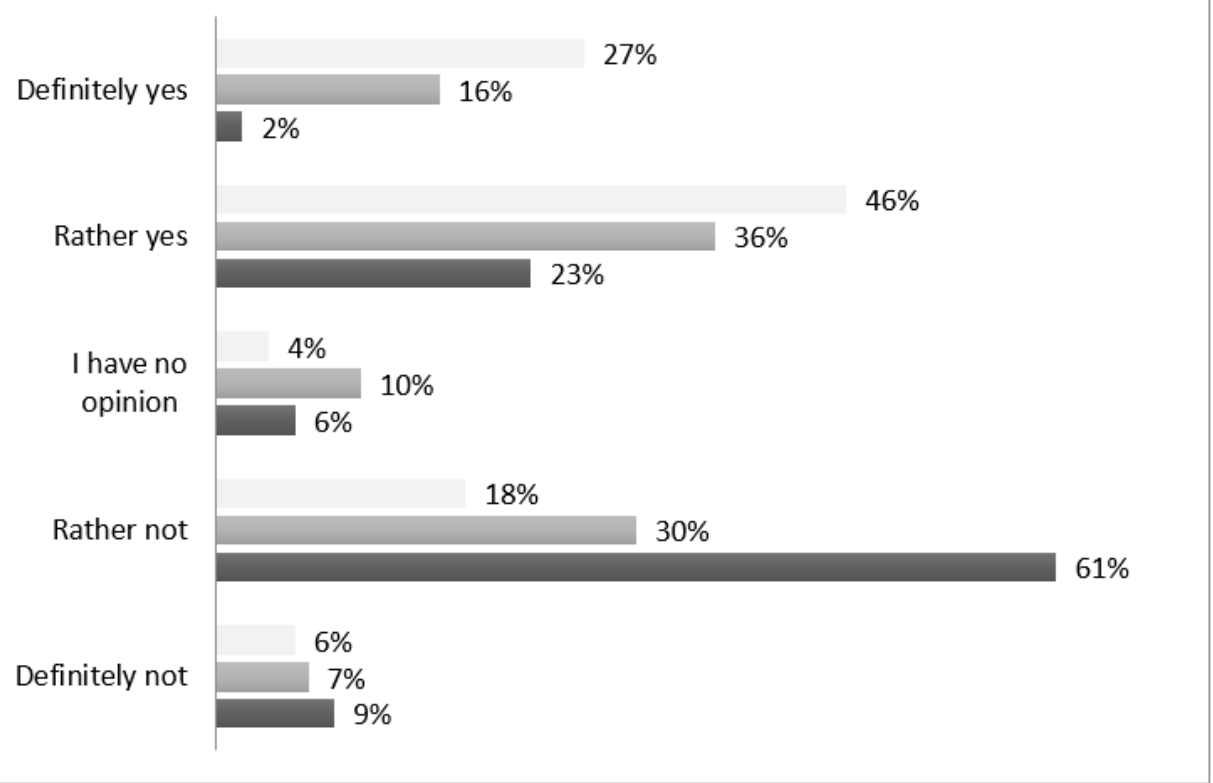

Figure 1. Experts' opinions on the idea of sustainable development (SD). Source: author's own compilation based on conducted research.

Table 1. The profile of respondents.

\begin{tabular}{ccccccc}
\hline Variable & Category & $\begin{array}{c}\text { Economic } \\
\text { Sciences }\end{array}$ & $\begin{array}{c}\text { Natural } \\
\text { Sciences }\end{array}$ & $\begin{array}{c}\text { Social } \\
\text { Sciences }\end{array}$ & $\begin{array}{c}\text { Technical } \\
\text { Sciences }\end{array}$ & Total \\
\hline \multirow{5}{*}{ Age } & up to 35 years & 5 & 7 & 2 & 3 & 17 \\
\cline { 2 - 7 } & $36-45$ years & 28 & 11 & 3 & 3 & 45 \\
\cline { 2 - 7 } & $46-55$ years & 14 & 3 & 1 & 3 & 21 \\
\cline { 2 - 7 } & more than 55 years & 12 & 8 & 1 & 1 & 22 \\
\cline { 2 - 7 } & Final sum & $\mathbf{5 9}$ & $\mathbf{2 9}$ & $\mathbf{7}$ & $\mathbf{1 0}$ & $\mathbf{1 0 5}$ \\
\hline \multirow{3}{*}{ Education } & MSc & 7 & 8 & 5 & 3 & 23 \\
\cline { 2 - 7 } & PhD & 28 & 12 & 2 & 5 & 47 \\
\cline { 2 - 7 } & Associate prof. & 13 & 7 & 0 & 0 & 20 \\
\cline { 2 - 7 } & Professor & 11 & 2 & 0 & 2 & 15 \\
\cline { 2 - 7 } & Final sum & $\mathbf{5 9}$ & $\mathbf{2 9}$ & $\mathbf{7}$ & $\mathbf{1 0}$ & $\mathbf{1 0 5}$ \\
\hline
\end{tabular}


Table 1. Cont.

\begin{tabular}{ccccccc}
\hline Variable & Category & $\begin{array}{c}\text { Economic } \\
\text { Sciences }\end{array}$ & $\begin{array}{c}\text { Natural } \\
\text { Sciences }\end{array}$ & $\begin{array}{c}\text { Social } \\
\text { Sciences }\end{array}$ & $\begin{array}{c}\text { Technical } \\
\text { Sciences }\end{array}$ & Total \\
\hline \multirow{4}{*}{$\begin{array}{c}\text { Unit } \\
\text { represented }\end{array}$} & association & 2 & 4 & 0 & 1 & 7 \\
\cline { 2 - 7 } & foundation & 4 & 2 & 0 & 0 & 6 \\
\cline { 2 - 7 } & research institute & 23 & 6 & 1 & 1 & 31 \\
\cline { 2 - 7 } & university & 34 & 21 & 0 & 0 & 55 \\
\cline { 2 - 7 } & administration & 0 & 3 & 6 & 9 & 18 \\
\cline { 2 - 7 } & Final sum & $\mathbf{6 3}$ & $\mathbf{3 6}$ & $\mathbf{7}$ & $\mathbf{1 1}$ & $\mathbf{1 1 7}^{*}$ \\
\hline
\end{tabular}

Source: author's own compilation based on conducted research. ${ }^{*}$ The final sum for the represented unit is higher because some experts declared their membership in more than one organization.

\section{Results and Discussion}

As of October 2018, 105 experts, representing numerous institutions and scientific fields, had completed the questionnaire. The age structure was dominated $(41 \%)$ by middle-aged people from 36 years to 45 years old. In terms of the education level, the sample was dominated by respondents with a $\mathrm{PhD}(43 \%)$. Those with master's degrees were employees of government administration offices and units or research institutes. University employees dominated among those with doctoral, postdoctoral, and professorial degrees. When specifying their affiliation to a unit, a respondent could give more than one answer (e.g., being both an employee of a university and a member of an association or research institute). The experts were dominated by university employees. Research units and institutes also had plenty of representation. Economists clearly dominated among the respondents. These sciences were represented by $56 \%$ of respondents. The relatively high proportion of representatives from this field of science was somewhat intentional. This is because, as already noted, it is the economists who have significant responsibility for the shape and direction of development, its durability and balance. Nevertheless, the survey also included representatives from other sciences: technical, social, and natural sciences (Table 1). Thus, the opinions of economists were related to the opinions of representatives of other scientific disciplines. This is because there are most often differences in interpretations and views on SD implementation at their interface. Thanks to the fact that, in addition to economists, 46 representatives of other sciences completed the questionnaire, it became possible to examine to what extent the represented field of study differentiated the experts' views.

A clear majority of experts expressed the view that sustainable development has become a paradigm of modern civilization (Figure 1). As many as $73 \%$ of respondents confirmed such an opinion, with strong opinions prevailing (certainty/no doubt equaled $46 \%$ of respondents).

However, with regard to the question whether the legally binding definition of sustainable development was formulated properly (i.e., in such a way that not only the authorities but all citizens should feel like addressees), the respondents were not so decisive. The percentage of experts responding positively to this definition was $52 \%$, but answers allowing for doubt (rather yes, 36\%) predominated.

Nevertheless, the real weakness of sustainable development foundations was revealed when respondents were asked about the principles of sustainable development: are they so well understood by the public that in everyday life they can be informed and active implementers of them? Here, in the structure expressed on the same scale, negative answers clearly dominated ( $70 \%$ of the respondents). Only $11 \%$ of respondents felt that the rules were clear to the public (Figure 1).

The results supported both the conclusions drawn from the theoretical review and the authors' own observations. Sustainable development is a circulating term, often a marketing ploy of companies, or a popular slogan of strategies and plans. We still have doubts with regard to what it is actually supposed to be and what exactly it should be, and what principles we should follow. 
Therefore, in the next step, experts were presented with a series of synthetic definitions and asked to assess whether they were convincing: do they provide the necessary guidance to the public? The responses were analyzed by the field of study represented (Table 2).

Table 2. Evaluation of selected definitions of SD in terms of the best possible explanation of the essence of the idea of sustainable development to society (i.e., so that every citizen can realize the idea of SD in everyday life).

\begin{tabular}{|c|c|c|c|c|c|c|}
\hline & \multirow[t]{2}{*}{ Definition of Sustainable Development } & \multicolumn{5}{|c|}{$\begin{array}{l}\text { Percentage of Respondents Who Found the Definition } \\
\text { Convincing (by Scientific Discipline * and Total) }\end{array}$} \\
\hline & & $\mathbf{E}$ & $\mathbf{N}$ & $S$ & $\mathbf{T}$ & Total \\
\hline D1 & $\begin{array}{l}\text { Development that meets the needs of the present } \\
\text { without compromising the ability of future } \\
\text { generations to meet their own needs }\end{array}$ & 73 & 83 & 86 & 90 & 78 \\
\hline D2 & $\begin{array}{l}\text { Simultaneous maximization of the goals of } \\
\text { systems: biological, economic, and social }\end{array}$ & 36 & 45 & 29 & 20 & 36 \\
\hline D3 & $\begin{array}{l}\text { Shaping the right relationship between dynamic } \\
\text { systems: economic and ecological }\end{array}$ & 39 & 45 & 71 & 10 & 40 \\
\hline D4 & $\begin{array}{l}\text { Striving for constructiveness, so that each } \\
\text { element of the system fosters the development of } \\
\text { other elements }\end{array}$ & 31 & 28 & 43 & 30 & 30 \\
\hline D5 & $\begin{array}{l}\text { Dynamic optimization process: minimizing } \\
\text { environmental damage while maximizing } \\
\text { environmental benefits }\end{array}$ & 54 & 62 & 71 & 70 & 59 \\
\hline D6 & $\begin{array}{l}\text { Ensuring durable improvement in the quality of } \\
\text { life of generations through the formation and } \\
\text { implementation of appropriate proportions } \\
\text { between economic, human, and natural capital }\end{array}$ & 59 & 69 & 86 & 60 & 64 \\
\hline D7 & $\begin{array}{l}\text { Socio-economic development balanced with the } \\
\text { environment, consistent with social expectations } \\
\text { and aspirations in terms of prospects for } \\
\text { satisfying needs and self-fulfillment }\end{array}$ & 56 & 52 & 71 & 50 & 55 \\
\hline D8 & $\begin{array}{l}\text { Striving to achieve a balance between the various } \\
\text { objectives of socio-economic development, } \\
\text { ensuring the long-term durability of the system }\end{array}$ & 51 & 59 & 43 & 50 & 52 \\
\hline D9 & $\begin{array}{l}\text { Development in which every individual is } \\
\text { guaranteed the right to life, free activity, and } \\
\text { property, provided that, in exercising these rights, } \\
\text { they do not deprive other individuals of the same }\end{array}$ & 54 & 69 & 86 & 80 & 63 \\
\hline D10 & $\begin{array}{l}\text { Striving to live consciously and maturely in } \\
\text { harmony within and with the environment }\end{array}$ & 54 & 72 & 86 & 40 & 60 \\
\hline
\end{tabular}

${ }^{*}$ E-economic sciences, N-natural sciences, S-social sciences, T-technical sciences. Source: Own study.

Experts' opinions on a number of alternative definitions of D1-D10 in the light of the calculated $\chi^{2}$ statistic were varied due to the disciplines represented (Tables 2 and 3 ).

Table 3. Chi-Square Test result.

\begin{tabular}{cccc}
\hline & Value & df & $\begin{array}{c}\text { Asymptotic Significance } \\
\text { (2-Sided) }\end{array}$ \\
\hline Pearson Chi-Square & $72,979 *$ & 27 & 0,000 \\
\hline Likelihood Ratio & 80,022 & 27 & 0,000 \\
\hline Linear-by-Linear Association & 0,651 & 1 & 0,420 \\
\hline * cells have expected count less than 5. Source: Own study. &
\end{tabular}


Observing the calculated proportions for individual disciplines (Table 2), it can be noticed that the differences in the views of Polish experts were the greatest in relation to the definitions D3 and D10. On the other hand, relatively smaller differences in opinions were recorded in the case of definitions D4, D7, and D8. Nevertheless, the calculated value of the Pearson Chi-Square statistics $=72.979$ with $\mathrm{df}=27$ (Table 3 ) and Sig. $=0.000$ indicated that there are grounds for rejecting the hypothesis that there is no correlation between the opinion on particular definitions of SD and the scientific discipline represented.

In light of the responses, it can be seen that the respondents (and especially the technical science representatives) considered the intergenerational equity context (D1) as the most convincing explanation of SD.

Overall, the interpretive value of system definitions (D2, D3, D4) was poorly evaluated (all gaining approval from up to $40 \%$ of respondents). Thus, in the opinion of the vast majority of experts, these were unconvincing interpretations.

It is worth checking which of the other definitions were found to be convincing. Definition D6 was highly rated (overall 64\% approval). Korol's proposal [43] emphasized the need to ensure durable improvement in the quality of life for generations within SD. According to Korol, this improvement was to be achieved through the formation and implementation of appropriate proportions between economic, human, and natural capital. However, in the case of the D9 interpretation, the results were surprising-just as the authors were surprised by the rejection of the system proposals. Let us recall that D9 is a manifesto of economic liberalism expressed by Bastiat [93] long before the rise of interest in the idea of SD on the international arena. The simple principles of liberalism were considered by $63 \%$ of respondents to capture the essence of sustainability well. Interestingly, the percentage of economists convinced by this interpretation was the lowest (54\%). This definition was particularly liked by representatives of the social sciences $(86 \%)$ and technical sciences (80\%).

None of the definitions directly addressed energy-related problems. Nevertheless, virtually each of them had some potential to change and shape this sphere of human life and activity as well. It is worth noting, for example, the system definitions D4 (postulates that each element of the system should foster the development of other elements), D5 (postulates that losses in the environment should be minimized, while benefits from its management should be maximized), and proposal D9 (postulates that while exercising one's rights, one should not deprive other individuals of those same rights).

\section{Conclusions}

Kurt Gödel, an Austrian logician and mathematician, author of theorems in mathematical logic, put forward an interesting discovery. He stated that as complexity increases, any theoretical system gradually loses its coherence and becomes illogical. This reflection provides a simple explanation for the controversy surrounding sustainable development and attempts to operationalize it. Gödel came to the conclusion that the better the foundations of a system are formulated, the more precisely its original concepts, postulates, and certainties are defined, the later its final disintegration resulting from the inevitable further theoretical expansion can occur [94].

The essence of durability in the paradigm of sustainable development, the possibility of its implementation, continuation, and development is closely related to the consistency of the basic assumptions and axioms of this idea; just as the quality of a house's foundations determines the possibility of an extension being built. Meanwhile, the foundations of sustainability appear to be inconsistent, both from the perspective of economics itself, and at the interface of that science with philosophy and ecology.

According to philosopher Thomas Kuhn, a good paradigm must be logically and conceptually consistent. It must also be as simple as possible and contain only those concepts and theories that are truly essential to the science in question. Furthermore, it should provide the ability to create detailed theories that are consistent with observed facts [95]. This raises the need to seek the simplest possible definition of sustainable 
development. A definition that will refer to humans as the subjects of this paradigm and give a simple and unambiguous indication of how they should act.

Despite statistically significant differences in opinions by discipline, the research showed that the majority of Polish experts approved of the classic understanding of the concept of SD: emphasizing the context of intergenerational justice. Overall, none of the alternative definitions were more widely accepted by the respondents. However, when looking at individual disciplines, it is worth paying attention to social sciences: their representatives similarly assessed the classical definition D1 and as many as three alternative definitions: D6, D9, and D10. Thus, it was among the representatives of social sciences that the approval for other views on SD was the greatest. However, it was among the representatives of social sciences that the approval for other views on SD was the greatest. Let us note one more paradox: as many as $78 \%$ of Polish experts were convinced by the classic definition of D1. However, they also admitted that its development applied in Polish legislation meant that citizens do not have to feel like addressees, let alone conscious and active implementers of SD.

The theoretical foundations of sustainable development have been, are, and probably will continue to be formulated on the borderline between socio-economic, natural, and technical sciences. The contribution of economics is important and undeniable, although different schools and trends of this field of knowledge treat natural capital, the issue of durability, and the problem of the valuation of environmental goods and services in different ways. However, one can get the impression that the process of creating new definitions and developing the theory of sustainable development touches the essence of the problem to a small extent. Although issues of sustainable development have been addressed in the inquiries of representatives of various fields of knowledge, the issue of the individual is missed. The human being, as a subject and implementer of sustainable development, should be the focus of attention of researchers dealing with this issue. For it is impossible for an unsustainable human being to develop sustainably. Therefore, the problem of human capital is one of the most urgent and important problems of modern globalizing society [96]. On the other hand, sustainable development seems unlikely to a disoriented person, for whom the balance of ecosystems, durability, and natural capital, and the problem of its substitution and intergenerational equity are abstract concepts and issues with little or no bearing on everyday life. The average person, increasingly deprived by the media of the capacity for independent thought, reflection, and criticism, needs simple rules so that he or she can consciously contribute to the implementation of sustainable development in his or her life. That is exactly what a modern definition of this development should be-short and concise, telling one what to do, and specific and focused on the individual.

Author Contributions: Conceptualization, M.D.; methodology, A.P.; software, M.D. and A.P.; validation, M.D., A.P., Ł.S., A.D.; formal analysis, M.D., A.P., Ł.S., A.D.; investigation, M.D. and A.P.; resources, M.D. and A.P.; data curation, M.D., A.P., Ł.S., A.D.; writing—original draft preparation, M.D., A.P., Ł.S., A.D.; writing-review and editing, M.D., A.P., Ł.S., A.D.; visualization, M.D. and A.P.; supervision, Ł.S.; project administration, M.D. All authors have read and agreed to the published version of the manuscript.

Funding: This research was financed from the Ministry of Education and Science funds for the statutory activity of the University of Agriculture in Krakow (R 314/272/2021).

Institutional Review Board Statement: Not applicable.

Informed Consent Statement: Not applicable.

Data Availability Statement: Not applicable.

Conflicts of Interest: The authors declare no conflict of interest. 


\section{References}

1. Toffler, A. Future Shock; Bantam Books: New York, NY, USA, 1970; p. 25.

2. British Petroleum. BP Statistical Review of World Energy. 2019. Available online: https://www.bp.com/en/global/corporate/ energy-economics/statistical-review-of-world-energy.html (accessed on 27 November 2019).

3. Berdo, J. Zrównoważony Rozwój. W Stronę Życia w Harmonii z Przyroda; Earth Conservation: Sopot, Poland, $2006 ;$ p. 48.

4. The World Counts. 2019. Available online: http://www.theworldcounts.com/ (accessed on 15 September 2019).

5. Meadows, D.H.; Meadows, D.L.; Randers, J.; Behrens, W.W. Granice Wzrostu; PWE: Warszawa, Poland, 1973 ; pp. 88, $123-145$.

6. Brown, L. Plan B: Rescuing a Planet Under Stress and a Civilization in Trouble; Earth Policy Institute: Norton, NY, USA, $2003 ;$ pp. 7-15.

7. Brown, L. Eco-Economy: Building an Economy for the Earth; Earth Policy Institute: Norton, NY, USA, $2001 ;$ pp. 17-19.

8. Norouzi, N.; Fani, M.; Ziarani, Z. The fall of oil Age: A scenario planning approach over the last peak oil of human history by 2040. J. Pet. Sci. Eng. 2020, 188, 106827. [CrossRef]

9. Transforming Our World: The 2030 Agenda for Sustainable Development. Available online: https://www.un.org/ga/search/ view_doc.asp?symbol=A/RES/70/1\&Lang=E (accessed on 29 June 2021).

10. Kamali-Chirani, F. Intercultural Dialogue for Sustainable Development. J. Dev. Policy Res. Pract. 2020, 3-4, 1-25.

11. He, P.; Ng, T.S.; Su, B. Energy-economic recovery resilience with Input-Output linear programming models. Energy Econ. 2017, 68, 177-191. [CrossRef]

12. Green, E.C. Paper-Towards a European Strategy for the Security of Energy Supply; Office for Official Publications of the European Communities; European Commission: Luxembourg, 2001.

13. Pasqualetti, M.J.; Sovacool, B.K. The importance of scale to energy security. J. Integr. Environ. Sci. 2012, 9, 167-180. [CrossRef]

14. Resolution Adopted by the General Assembly on 6 July 2017 A/RES/71/313. Available online: https://undocs.org/A/RES/71 /313 (accessed on 18 May 2021).

15. Sustainable Development in the European Union; 2013 Monitoring Report of the EU Sustainable Development Strategy; Eurostat Statistical Books; European Union: Luxembourg, 2013; p. 20.

16. Yumashev, A.; Ślusarczyk, B.; Kondrashev, S.; Mikhaylov, A. Global indicators of sustainable development: Evaluation of the influence of the human development index on consumption and quality of energy. Energies 2020, 13, 2768. [CrossRef]

17. European Commission. Communication from the Commission to the European Parliament, the Council, the European Economic and Social Committee and the Committee of the Regions Closing the Loop-An EU Action Plan for the Circular Economy. COM/2015/0614 Final. Available online: https:/ / eur-lex.europa.eu/legal-content/EN/TXT/?uri=CELEX\%3A52015DC0614 (accessed on 24 June 2021).

18. Martí-Ballester, C.-P. Do European renewable energy mutual funds foster the transition to a low-carbon economy? Renew. Energy 2019, 143, 1299-1309. [CrossRef]

19. Vanhamäki, S.; Virtanen, M.; Luste, S.; Manskinen, K. Transition towards a circular economy at a regional level: A case study on closing biological loops. Resour. Conserv. Recycl. 2020, 156, 104716. [CrossRef]

20. Goldthau, A.; Sovacool, B.K. The uniqueness of the energy security, justice, and governance problem. Energy Policy 2012, 41, 232-240. [CrossRef]

21. Bridge, G.; Bouzarovski, S.; Bradshaw, M.; Eyre, N. Geographies of energy transition: Space, place and the low-carbon economy. Energy Policy 2013, 53, 331-340. [CrossRef]

22. Böhringer, C.; Rutherford, T.F. Transition towards a low carbon economy: A computable general equilibrium analysis for Poland. Energy Policy 2013, 55, 16-26. [CrossRef]

23. Stern, N. The economics of climate change. Am. Econ. Rev. 2008, 98, 1-37. [CrossRef]

24. Simkiv, L.; Shults, S.; Lutskiv, O.; Andrusiv, U. Analysis of the Dynamics of Structural Processes in the Context of Ensuring Sustainable Development. Eur. J. Sustain. Dev. 2021, 10, 153. [CrossRef]

25. Mebratu, D. Sustainability and sustainable development: Historical and conceptual review. Environ. Impact Assess. Rev. 1998, 18, 493-520. [CrossRef]

26. Pearce, D.W.; Atkinson, G.D. Capital theory and the measurement of sustainable development: An indicator of "weak" sustainability. Ecol. Econ. 1993, 8, 103-108. [CrossRef]

27. Turner, R.K.; Pearce, D.W. Sustainable economic development: Economic and ethical principles. In Economics and Ecology; Barbier, E.B., Ed.; Springer: Dordrecht, The Netherlands, 1993; pp. 177-194.

28. Alonso, P.M.; Hewitt, R.; Pacheco, J.D.; Bermejo, L.R.; Jiménez, V.H.; Guillén, J.V.; Bressers, H.; de Boer, C. Losing the roadmap: Renewable energy paralysis in Spain and its implications for the EU low carbon economy. Renew. Energy 2016, 89, 680-694. [CrossRef]

29. Krepl, V.; Shaheen, H.I.; Fandi, G.; Smutka, L.; Muller, Z.; Tlustý, J.; Husein, T.; Ghanem, S. The Role of Renewable Energies in the Sustainable Development of Post-Crisis Electrical Power Sectors Reconstruction. Energies 2020, 13, 6326. [CrossRef]

30. Medved, P.; Kim, J.I.; Ursic, M. The urban social sustainability paradigm in Northeast Asia and Europe A comparative study of sustainable urban areas from South Korea, China, Germany and Sweden. Int. Rev. Spat. Plan. Sustain. Dev. 2020, 8, $16-37$.

31. Yandri, P.; Priyarsono, D.S.; Fauzi, A.; Dharmawan, A.H. Formulating and Validating Sustainable Residential Area Indicators in Suburban Metropolitan Jakarta. Int. Rev. Spat. Plan. Sustain. Dev. 2021, 9, 82-102.

32. Dacko, M.; Dacko, A. Dylematy zrównoważonego rozwoju polskiego rolnictwa. Rocz. Nauk. Stowarzyszenia Ekon. Rol. Agrobiz. 2011, 8, 33-38. 
33. Zaiets, O.; Vlasenko, Y.; Busuyok, D.; Pozniak, E. Ecological Aspect of Legal Provision of Modern Land Reform as a Factor of Sustainable Development. Eur. J. Sustain. Dev. 2021, 10, 168. [CrossRef]

34. Streimikiene, D.; Ciegis, R.; Grundey, D. Energy indicators for sustainable development in Baltic States. Renew. Sustain. Energy Rev. 2007, 11, 877-893. [CrossRef]

35. Lyeonov, S.; Pimonenko, T.; Bilan, Y.; Štreimikienè, D.; Mentel, G. Assessment of Green Investments' Impact on Sustainable Development: Linking Gross Domestic Product Per Capita, Greenhouse Gas Emissions and Renewable Energy. Energies 2019, 12, 3891. [CrossRef]

36. Daly, H.E. Sustainable development-Definitions, principles, policies. In The Future of Sustainability; Keiner, M., Ed.; Springer: Dordrecht, The Netherlands, 2006; pp. 39-53.

37. Saremi, P. The Role of Environmental Engineering in Sustainable Economic Development. Asian J. Agric. Life Sci. $2019,4,6-16$.

38. Carlowitz, H.C. Sylvicultura, Oder haußwirthliche Nachricht und Naturmäßige Anweisung zur wilden Baum-Zucht, 1st ed.; Braun: Leipzig, Germany, 1713; pp. 105-106. Available online: http://www.zeit.de/1999/48/Der_Erfinder_der_Nachhaltigkeit (accessed on 14 May 2021).

39. Isa, N.M.; Sivapathy, A.; Adjrina Kamarruddin, N.N. Malaysia on the Way to Sustainable Development: Circular Economy and Green Technologies. In Modeling Economic Growth in Contemporary Malaysia (Entrepreneurship and Global Economic Growth); Sergi, B.S., Jaaffar, A.R., Eds.; Emerald Publishing Limited: Bingley, UK, 2021; pp. 91-115. [CrossRef]

40. World Conservation Strategy. International Union for Conservation of Nature and Natural Resources. Available online: http:/ / data.iucn.org/dbtw-wpd/edocs/WCS-004.pdf (accessed on 19 May 2021).

41. Redek, T.; Domadenik, P.; Koman, M. Sustainable Development Goals in the EU and the Challenges in Their Implementation. In Challenges on the Path Toward Sustainability in Europe; Žabkar, V., Redek, T., Eds.; Emerald Publishing Limited: Bingley, UK, 2020; pp. 11-29. [CrossRef]

42. Report of the World Commission on Environment and Development: Our Common Future. Available online: http://www.undocuments.net/wced-ocf.htm (accessed on 28 May 2021).

43. Korol, J. Wskaźniki Zrównoważonego Rozwoju w Modelowaniu Procesów Regionalnych, 1st ed.; Wydawnictwo Adam Marszałek: Torun, Poland, 2007; pp. 78-122.

44. Dobson, A. Environmental Sustainabilities: An analysis and a typology. Environ. Politics 1996, 5, 401-428. [CrossRef]

45. Klarin, T. The Concept of Sustainable Development: From its Beginning to the Contemporary Issues. Int. Rev. Econ. Bus. 2018, 21, 67-94. [CrossRef]

46. Renko, S. The Concept of Sustainable Development. In The Sustainable Marketing Concept in European SMEs; Rudawska, E., Ed.; Emerald Publishing Limited: Bingley, UK, 2018; pp. 29-52. [CrossRef]

47. Dernbach, J.C. Sustainable development as a framework for national governance. Case West. Reserve Law Rev. $1998,49,1$.

48. Dernbach, J.C. Achieving sustainable development: The Centrality and multiple facets of integrated decision making. Indiana J. Glob. Leg. Stud. 2003, 10, 247-285. [CrossRef]

49. Lele, S.M. Sustainable development: A critical review. World Dev. 1991, 19, 607-662. [CrossRef]

50. Stoddart, H.; Bottero, M.; Cornforth, J.; Dodds, F.; Lingan, J.; Schneeberger, K.; Shaw, A.; Smith, N.; Strachan, J.; White, R. A Pocket Guide to Sustainable Development Governance, 2nd ed.; Commonwealth Secretariat and Stakeholder Forum, United Nations: Rome, Italy, 2011; pp. 1-155.

51. Mensah, J.; Casadevall, S.R. Sustainable development: Meaning, history, principles, pillars, and implications for human action: Literature review. Cogent Soc. Sci. 2019, 5, 1653531. [CrossRef]

52. Harwood, R.R. The history of sustainable agriculture. In Sustainable Farming Systems, 1st ed.; Edwards, C.A., Lal, R., Madden, P., Miller, R., House, G., Eds.; CRC Press: Boca Raton, FL, USA, 1990; pp. 3-19.

53. International Union for Conservation of Nature and Natural Resources; United Nations Environmental Programme; World Wildlife Fund for Nature. Caring for the Earth. A Strategy for Sustainable Living. Environ. Values 1992, 1, 171-173.

54. Sterling, S. Learning for resilience, or the resilient learner? Towards a necessary reconciliation in a paradigm of sustainable education. Environ. Educ. Res. 2010, 16, 511-528. [CrossRef]

55. Marin, C.; Dorobanțu, R.; Codreanu, D.; Mihaela, R. The Fruit of Collaboration between Local Government and Private Partners in the Sustainable Development Community Case Study: County Valcea. Econ. Transdiscipl. Cogn. 2012, 2, 93-98.

56. Beck, U.; Wilms, J. Conversations with Ulrich Beck; Polity Press: Cambridge, UK, 2004.

57. Dacko, M.; Płonka, A. Secondary school youth and the idea of sustainable development-Opinions and attitudes. Sci. Pap. Sil. Univ. Technol. Organ. Manag. 2019, 139, 489-502.

58. Runowski, H. Rozwój Zrównoważony Rolnictwa i Gospodarstw Rolniczych. Wieś i Rolnictwo—Perspektywy Rozwoju; Wyd. IERiGŻ, IRWiR PAN, SGH-Katedra Agrobiznesu: Warszawa, Poland, 2002.

59. Mohieldin, M. The Sustainable Development Goals and Private Sector Opportunities; World Bank Group: Medellin, Colombia, 2017; pp. 1-53.

60. Bagheri, A.; Hjorth, P. Planning for sustainable development: A paradigm shift towards a process-based approach. Sustain. Dev. 2006, 15, 83-96. [CrossRef]

61. Martínez-Alier, J.; Pascual, U.; Vivien, F.D.; Zaccai, E. Sustainable de-growth: Mapping the context, criticisms and future prospects of an emergent paradigm. Ecol. Econ. 2010, 69, 1741-1747. [CrossRef] 
62. Nill, J.; Kemp, R. Evolutionary approaches for sustainable innovation policies: From niche to paradigm? Res. Policy 2009, 38, 668-680. [CrossRef]

63. Van der Waldt, G. Government interventionism and sustainable development: The case of South Africa. Afr. J. Public Aff. 2015, 8, 35-51.

64. Stacherzak, A.; Hełdak, M.; Hájek, L.; Przybyła, K. State interventionism in agricultural land turnover in Poland. Sustainability 2019, 11, 1534. [CrossRef]

65. Hull, Z. Sustainable development: Premises, understanding and prospects. Sustain. Dev. 2008, 16, 73-80. [CrossRef]

66. Ustawa z dn. 27.04.2001 r. Prawo Ochrony Środowiska (Act of April 27, 2001 Environmental Protection Law) (Dz. U. 2020 poz. 1219). Available online: https:/ /isap.sejm.gov.pl/isap.nsf/DocDetails.xsp?id=WDU20200001219 (accessed on 26 August 2021).

67. Ustawa z dn. 9.06.2011 r. Prawo Geologiczne i Górnicze (Act of June 9, 2011 Geological and Mining Law) (Dz. U. 2021 poz. 1420). Available online: https:/ /isap.sejm.gov.pl/isap.nsf/DocDetails.xsp?id=WDU20210001420 (accessed on 26 August 2021).

68. Ustawa z dn. 20.07.2017 r. Prawo Wodne (Act of July 20, 2017 Water Low Act) (Dz. U. 2021 poz. 624). Available online: https:/ / isap.sejm.gov.pl/isap.nsf/DocDetails.xsp?id=WDU20210000624 (accessed on 26 August 2021).

69. Ustawa z dn. 28.09.1991 r. o Lasach (Act of September 28, 1991 Forest Act) (Dz. U. 2021 poz. 1275). Available online: https:/ /isap.sejm.gov.pl/isap.nsf/DocDetails.xsp?id=WDU20210001275 (accessed on 26 August 2021).

70. Ustawa z dnia 14.12.2012 r. o Odpadach (Act of December 14, 2012 Waste Act) (Dz. U. 2021 poz. 779). Available online: https:/ /isap.sejm.gov.pl/isap.nsf/DocDetails.xsp?id=WDU20210000779 (accessed on 26 August 2021).

71. Bertalanffy, L.; Sutherland, J.W. General Systems Theory: Foundations, Developments, and Applications; Braziller: New York, NY, USA, 1974.

72. Zabłocki, G. Rozwój Zrównoważony-Idee, Efekty, Kontrowersje; Wyd. UMK: Torun, Poland, 2002.

73. Holmberg, J.; Sandbrook, R. Sustainable development: What is to be done? In Policies for a Small Planet, 1st ed.; Routledge: New York, NY, USA, 2019; pp. 19-38.

74. World Commission on Environment and Development. Our Common Future; Oxford University Press: Oxford, UK, 1987.

75. Blewitt, J. Understanding Sustainable Development, 2nd ed.; Routledge: New York, NY, USA, 2015.

76. Weiner, J. Życie i Ewolucja Biosfery; PWN: Warszawa, Poland, 2006.

77. Sandner, J. Zrównoważony Rozwój Szansą Dla Ludzkości; Wyd. Uniwersytetu Kardynała Stefana Wyszyńskiego: Warszawa, Poland, 2008.

78. Von Mises, L. Human Action: A Treatise on Economics, 3rd ed.; Contemporary Books Inc.: Chicago, IL, USA, 1966.

79. Lacko, R.; Hajduová, Z.; Zawada, M. The efficiency of circular economies: A comparison of Visegrád Group Countries. Energies 2021, 14, 1680. [CrossRef]

80. Colander, D.; Landreth, H. History of Economic Theory; Houghton Mifflin: Boston, MA, USA, 1989.

81. Jeżowski, P. Kategoria rozwoju zrównoważonego w naukach ekonomicznych. In Ekonomiczne Problemy Ochrony Środowiska $i$ Rozwoju Zrównoważonego w XXI Wieku; Jeżowski, P., Ed.; Wyd. SGH: Warszawa, Poland, 2007.

82. Bołtromiuk, A. Ekonomiczne Aspekty Funkcjonowania Obszarów Chronionych; Wyd. UwB: Białystok, Poland, 2003.

83. Borys, T. Koncepcja zrównoważonego rozwoju w naukach ekonomicznych. In Ekonomia Zrównoważonego Rozwoju. Zarys Problemów Badawczych i Dydaktyki; Poskrobko, B., Ed.; Wyd. WSE: Białystok, Poland, 2010.

84. Żylicz, T. Czy studentów ekonomii należy uczyć o trwałym rozwoju? Ekonomia zrównoważonego rozwoju. In Zarys Problemózw Badawczych i Dydaktyki; Poskrobko, B., Ed.; Wyd. WSE: Białystok, Poland, 2010.

85. Sztumski, W. Idea zrównoważonego rozwoju a możliwości jej urzeczywistnienia. Probl. Ekorozw. 2006, 1, 73-76.

86. Bajerowski, T. Podstawy Teoretyczne Gospodarki Przestrzennej i Zarzadzania Przestrzenia; Wyd. UWM: Olsztyn, Poland, 2003.

87. Domański, R. Geografia Ekonomiczna. Ujęcie Dynamiczne; PWN: Warszawa, Poland, 2004.

88. Barbier, E.B. The concept of sustainable economic development. Environ. Conserv. 1987, 14, 101-110. [CrossRef]

89. Costanza, R. The ecological economics of sustainability. In Environmentally Sustainable Economic Development: Building on Brundtland; Goodland, R., Daly, H., El Serafy, S., von Droste, B., Eds.; UNESCO: Paris, France, 1991; pp. 83-90.

90. Rogall, H. Ekonomia zrównoważonego rozwoju—Potrzeba reformy tradycyjnej ekonomii, Ekonomia zrównoważonego rozwoju. In Zarys Problemów Badawczych i Dydaktyki; Poskrobko, B., Ed.; Wyd. WSE: Białystok, Poland, 2010.

91. Michnowski, L. Jak żyć? Ekorozwój albo? Wyd. Ekonomia i Środowisko: Białystok, Poland, 1995.

92. Kiełczewski, D. Zrównoważony rozwój-Istota, interpretacje, związek ze społeczeństwem wiedzy. In Ekonomia Zrównoważonego Rozwoju; Materiały do studiowania; Poskrobko, B., Ed.; Wyd. WSE: Białystok, Poland, 2010.

93. Bastiat, F. Harmonies Économiques; Guillaumin: Paris, France, 1850.

94. Gödel, K. The Consistency of the Continuum Hypotesis; Annals of Mathematics Studies Princeton University Press: Princeton, NJ, USA, 1990; Volume 3.

95. Kuhn, T. The Structure of Scientific Revolutions; The University of Chicago Press: Chicago, IL, USA, 1962.

96. Gaffarova, G.G.; Jalalova, G.O. Human capital as the basis of society development. ISJ Theor. Appl. Sci. 2021, 4, 455-460. [CrossRef] 